\title{
Study of Conflict Management Style of D.El.Ed. Pupil Teachers
}

\author{
Santosh Pal \\ Research Scholar, Department of Education, University of Allahabad, Prayagraj, Uttar Pradesh, India.
}

\begin{abstract}
This research paper is an attempt to study the conflict management style of pupil teachers. D.El.Ed. course students ( $\mathrm{N}=96)$ were tested on Conflict Management Style. Conflict Management Style was assessed with the help of self-made Conflict Management Style Inventory. T-test and ANOVA were used to analyze the data and for post hoc analysis LSD test was used to determine the significance of intergroup differences. Study reveals that male and female pupil teachers of D.El.Ed. course give equal preference to adoption of 'Avoiding', 'Compromising', 'Collaborating', 'Integrating', and 'Reasoning' conflict management style. However, male pupil teachers give more preference to adoption of 'Dominating', and 'Obliging' conflict management in comparison to female pupil teachers. D.El.Ed. III semester pupil teachers adopt more 'Avoiding', and 'Compromising' conflict style than pupil teachers of D.El.Ed. I semester but students of both the semesters give equal priority to 'Collaborating', 'Integrating', 'Dominating', 'Obliging', and 'Reasoning' styles of conflict management. Pupil teachers of different localities and social background give equal preference to various conflict management styles.
\end{abstract}

Keywords: conflict management style; pupil teachers; grade level; gender; social category

DOI: $10.7176 /$ RHSS/9-7-03

Publication date: April $30^{\text {th }} 2019$

\section{Introduction}

Thomas (1976) defines conflict as "the process which begins when one party perceives that the other has frustrated, or is about to frustrate, some concern of his." Conflict is defined as a struggle over values and claims scarce status, power and resources, in which the aims of the opponent to neutralize, injure or eliminate the rivals Coser (1967). Thus interpersonal conflict arises in any setting where two or more people work together, Schramm-Nielsen (2002) thinks that conflict that it is the severe ill-feelings, mismatching and inconsistencies between /among individuals/groups. Therefore, Willmot and Hocker (2001) see it as "an articulated struggle". While Deutsch and Rahim (1992) see conflict as "incompatible activities" existing between the parties or individuals involved social situations. It may be due to existing differences on every possible dimensions like: age, gender, race, appearance, feelings, education, upbringing, experience, attitude, opinions, cultures, nations, religion, and so forth. In the present scenario, conflict continues to be a factor in the academic life of the students. In classrooms, it is a crucial, and an unavoidable phenomenon wherever human interaction exists or personal likes and dislikes matter. Our classrooms are no more exceptions, in same class and same group there exists an invisible second identity, which is garnered through socialization, and also plays vital role in selection of their perspectives. Our modern institutions are frequently appearing to be centers of invisible tension. Since, peace is not absence of conflict, it is the ability to handle conflict by peaceful means (Upadhyay, 2013). Therefore, teaching every student how to negotiate and mediate will ensure that future generations are prepared to manage conflicts constructively in career, family, community, national and international settings (Johnson \& Johnson, 1995). For a pupil teacher, who is proposed to be a teacher and role model for his forthcoming students, conflict management becomes more important part of teaching skill. As it is not core element of his mastery but it enriches the quality of teacher, because his students, as a learner, will try their best to acquire his all characteristics. This research paper is an attempt to study the conflict management style of D.El.Ed. pupil teachers.

\section{Objectives $^{1}$}

Objectives of the study are as follows-

1. To find out whether male and female pupil teachers differ from one another in their conflict management style.

2. To find out whether pupil teachers of D.El.Ed. I and D.El.Ed. III semester differ from one another in conflict management style.

3. To find out whether pupil teachers belonging to nuclear and joint families differ from one another in conflict management style.

4. To find out whether pupil teachers belonging to different social categories differ from one another in conflict management style.

\footnotetext{
${ }^{1}$ The objectives have been studied with reference to seven dimensions of conflict management style i.e. 'Avoiding', 'Compromising', 'Collaborating', 'Integration', 'Dominating', 'Obliging', and 'Reasoning' styles.
} 
Hypotheses ${ }^{1}$

The following hypotheses were tested-

1. There is no significant difference in conflict management style of male and female pupil teachers.

2. There is no significant difference in conflict management style of D.El.Ed. I and D.El.Ed. III semester pupil teachers.

3. There is no significant difference in conflict management style of pupil teachers belonging to urban and rural areas.

4. There is no significant difference in conflict management style of pupil teachers belonging to different social categories.

\section{Method}

Sample: The sample comprised of 92 participants (46 males, 46 females) of D.El.Ed. I and D.El.Ed. III semesters. Students were selected from two private training colleges of Lucknow, Uttar Pradesh, India.

Material and Procedures: Conflict Management Style was measured with the help of self-made 'Conflict Management Style Inventory'. This tool provides seven scores for styles of conflict management, namely'Avoiding', 'Compromising', 'Collaborating', 'Integrating', 'Dominating', 'Obliging', and 'Reasoning'. It is based on five point Likert type rating scale $(1=$ Strongly Disagree, $2=$ Disagree, $3=$ Not decided, $4=$ Agree, and $5=$ Strongly Agree). T-test, ANOVA were used to analyze the data.

\section{Results}

t-ratios were computed to compare male and female students on conflict management style. Means and standard deviations of conflict management style for male and female students are shown in table 1.

\section{Table 1}

Mean, SD, and t-ratios showing difference between male and female students on seven conflict management styles

\begin{tabular}{|c|c|c|c|c|c|c|c|}
\hline & GENDER & $\mathbf{N}$ & Mean & Std. Deviation & df & $\mathbf{t}$ & p-value \\
\hline \multirow{2}{*}{ Avoiding } & Male & 46 & 23.522 & 4.1779 & \multirow{2}{*}{90} & \multirow{2}{*}{1.171} & \multirow{2}{*}{.245} \\
\hline & Female & 46 & 22.500 & 4.1886 & & & \\
\hline \multirow{2}{*}{ Compromising } & Male & 46 & 24.043 & 5.4486 & \multirow{2}{*}{90} & \multirow{2}{*}{1.164} & \multirow{2}{*}{.248} \\
\hline & Female & 46 & 22.739 & 5.3017 & & & \\
\hline \multirow{2}{*}{ Collaborating } & Male & 46 & 31.391 & 4.2868 & \multirow{2}{*}{90} & \multirow{2}{*}{1.202} & \multirow{2}{*}{.233} \\
\hline & Female & 46 & 32.304 & 2.8587 & & & \\
\hline \multirow{2}{*}{ Integrating } & Male & 46 & 30.543 & 4.1671 & \multirow{2}{*}{90} & \multirow{2}{*}{.109} & \multirow{2}{*}{.913} \\
\hline & Female & 46 & 30.630 & 3.4536 & & & \\
\hline \multirow{2}{*}{ Dominating } & Male & 46 & 26.239 & 4.7243 & \multirow{2}{*}{90} & \multirow{2}{*}{$2.415^{*}$} & \multirow{2}{*}{.018} \\
\hline & Female & 46 & 23.870 & 4.6886 & & & \\
\hline \multirow{2}{*}{ Obliging } & Male & 46 & 22.283 & 4.9606 & \multirow{2}{*}{90} & \multirow{2}{*}{$3.028 * *$} & \multirow{2}{*}{.003} \\
\hline & Female & 46 & 19.326 & 4.3871 & & & \\
\hline \multirow{2}{*}{ Reasoning } & Male & 46 & 31.022 & 4.4095 & \multirow{2}{*}{90} & \multirow{2}{*}{1.040} & \multirow{2}{*}{.301} \\
\hline & Female & 46 & 31.848 & 3.0910 & & & \\
\hline
\end{tabular}

It was hypothesized that "There is no significant difference in conflict management style of male and female pupil teachers." This hypothesis was tested with reference to seven conflict management styles namely 'Avoiding', 'Compromising', 'Collaborating', 'Integration', 'Dominating', 'Obliging', and 'Reasoning' styles. The higher score on the conflict management style is indicative of higher exercise of that style of conflict management by the pupil teachers. On avoiding style, the difference between male $(M=23.522, S D=4.1779)$ and female $(M=22.500, S D=4.1886)$ pupil teachers is not significant $(\mathrm{t}=1.171)$ at 0.05 level. The similarity in adoption of avoiding style in male and female students appears to reflect social ethos as in paves the way to peace of mind. On compromising style, the difference between male $(M=24.0243, S D=5.4486)$ and female $(M$ $=22.739, S D=5.3017)$ pupil teachers is not significant $(\mathrm{t}=1.164)$ at 0.05 level. It means that students of both the genders give equal preference to adoption of compromising conflict management style. On collaborating style, the difference between male $(M=31.391, S D=4.2868)$ and female $(M=32.304, S D=2.8587)$ pupil teachers is not significant $(\mathrm{t}=1.202)$ at 0.05 level. It means that students of both the genders give equal preference to adoption of collaborating conflict management style. On integrating style, the difference between male $(M=30.543, S D=4.1671)$ and female $(M=30.630, S D=3.4536)$ pupil teachers is not significant $(\mathrm{t}=$ $0.109)$ at 0.05 level. It means that students of both the genders give equal preference to adoption of integrating

${ }^{1}$ The hypotheses have been tested with reference to seven dimensions of conflict management style i.e. 'Avoiding', 'Compromising', 'Collaborating', 'Integration', 'Dominating', 'Obliging', and 'Reasoning' styles. 
conflict management style. On dominating style, the difference between male $(M=26.239, S D=4.7243)$ and female $(M=23.870, S D=4.6886)$ pupil teachers is significant $(\mathrm{t}=2.415)$ at 0.05 level. It means that male pupil teachers give more preference to adoption of dominating style of conflict management in comparison to female pupil teachers. On obliging style, the difference between male $(M=22.283, S D=4.9606)$ and female $(M=$ $19.326, S D=4.3871)$ pupil teachers is significant $(\mathrm{t}=3.028)$ at 0.05 level. It means that male pupil teachers give more preference to adoption of obliging style of conflict management in comparison to their counter parts. On reasoning style, the difference between male $(M=31.022, S D=4.4095)$ and female $(M=31.848, S D=3.0910)$ pupil teachers is not significant $(\mathrm{t}=1.040)$ at 0.05 level. It means that students of both the genders give equal preference to adoption of reasoning conflict management style. Thus, it can be inferred that male and female pupil teachers of D.El.Ed. course give equal preference to adoption of 'Avoiding', 'Compromising', 'Collaborating', 'Integrating', and 'Reasoning' conflict management style. However, male pupil teachers give more preference to adoption of 'Dominating', and 'Obliging' conflict management in comparison to female pupil teachers. This gender difference in conflict management style is contrasting in comparison to findings of Pal and Misra (2018). Baxter and Shepard (1978) studied the sex role differences in terms of interpersonal conflict and found out that feminine persons disapprove of competition more than persons of masculine identification. Rahim (1983b) found that men are reportedly more obliging or accommodating as compared to women.

Table 2

Mean, SD, and t-ratios showing difference between D.EI.Ed. I and D.El.Ed. III semester students on seven conflict management styles

\begin{tabular}{|c|c|c|c|c|c|c|c|}
\hline Conflict management style & Class & $\mathbf{N}$ & Mean & Std. Deviation & df & t-ratio & p-value \\
\hline \multirow{2}{*}{ Avoiding } & D.El.Ed. I & 46 & 21.913 & 3.8112 & \multirow{2}{*}{90} & \multirow{2}{*}{$2.590^{*}$} & \multirow{2}{*}{.011} \\
\hline & D.El.Ed. III & 46 & 24.109 & 4.3062 & & & \\
\hline \multirow{2}{*}{ Compromising } & D.El.Ed. I & 46 & 22.283 & 5.2521 & \multirow{2}{*}{90} & \multirow{2}{*}{$2.007 *$} & \multirow{2}{*}{.048} \\
\hline & D.El.Ed. III & 46 & 24.500 & 5.3448 & & & \\
\hline \multirow{2}{*}{ Collaborating } & D.El.Ed. I & 46 & 31.609 & 3.8671 & \multirow{2}{*}{90} & \multirow{2}{*}{.626} & \multirow{2}{*}{.533} \\
\hline & D.El.Ed. III & 46 & 32.087 & 3.4501 & & & \\
\hline \multirow{2}{*}{ Integrating } & D.El.Ed. I & 46 & 30.261 & 4.4544 & \multirow{2}{*}{90} & \multirow{2}{*}{.820} & \multirow{2}{*}{.414} \\
\hline & D.El.Ed. III & 46 & 30.913 & 3.0392 & & & \\
\hline \multirow{2}{*}{ Dominating } & D.El.Ed. I & 46 & 24.913 & 5.0325 & \multirow{2}{*}{90} & \multirow{2}{*}{.279} & \multirow{2}{*}{.781} \\
\hline & D.El.Ed. III & 46 & 25.196 & 4.6696 & & & \\
\hline \multirow{2}{*}{ Obliging } & D.El.Ed. I & 46 & 19.891 & 4.6962 & \multirow{2}{*}{90} & \multirow{2}{*}{1.814} & \multirow{2}{*}{.073} \\
\hline & D.E1.Ed. III & 46 & 21.717 & 4.9561 & & & \\
\hline \multirow{2}{*}{ Reasoning } & D.El.Ed. I & 46 & 31.239 & 3.8308 & \multirow{2}{*}{90} & \multirow{2}{*}{.491} & \multirow{2}{*}{.625} \\
\hline & D.El.Ed. III & 46 & 31.630 & 3.8202 & & & \\
\hline
\end{tabular}

It was hypothesized that "There is no significant difference in conflict management style of students studying in D.El.Ed. I and D.El.Ed. III semester." This hypothesis was tested with reference to seven conflict management styles namely 'Avoiding', 'Compromising', 'Collaborating', 'Integration', 'Dominating', 'Obliging', and 'Reasoning' styles. Table 2 shows a comparison of students of D.El.Ed. I and D.El.Ed. III semester on seven dimensions of conflict management style. The higher score on the conflict management style is indicative of higher exercise of that style of conflict management by the students. On avoiding style, the difference between students of D.El.Ed. I $(M=21.913, S D=3.8112)$ and D.El.Ed. III $(M=24.109, S D=$ 4.3062) is significant $(\mathrm{t}=2.590)$ at 0.05 level. This significant difference in adoption of avoiding style for students of D.El.Ed. I and D.El.Ed. III semester provide a vital clue that grade level plays significant role in adoption of their avoiding style of conflict management. The comparison of compromising style shows that the D.El.Ed. I students' mean value is 22.283 with a standard deviation of 5.2521 and the D.El.Ed. III students' mean value is 24.500 with a standard deviation of 5.3448. It is clear that the difference between D.El.Ed. I and D.El.Ed. III semester is significant $(\mathrm{t}=2.007)$ at 0.05 level. It reveals that D.El.Ed. III semester pupil teachers adopt more compromising conflict style than pupil teachers of D.El.Ed. I semester. On collaborating style, the difference between students of D.El.Ed. I $(M=31.609, S D=3.8671)$ and D.El.Ed. III $(M=32.087, S D=$ $3.4501)$ semester is not significant $(\mathrm{t}=0.626)$ at 0.05 level. On integrating style, the difference between students of D.El.Ed. I $(M=30.261, S D=4.4544)$ and D.El.Ed. III $(M=30.913, S D=3.0392)$ semester is not significant $(\mathrm{t}=0.820)$ at 0.05 level. On dominating style, the difference between students of D.El.Ed. I $(M=24.913, S D=$ 5.0325 $)$ and D.El.Ed. III $(M=25.196, S D=4.6696)$ semester is not significant $(\mathrm{t}=0.279)$ at 0.05 level. On obliging style, the difference between students of D.El.Ed. I $(M=19.891, S D=4.6962)$ and D.El.Ed. III $(M=$ 21.717, $S D=4.9561)$ semester is not significant $(\mathrm{t}=1.814)$ at 0.05 level. On reasoning style, the difference between students of D.El.Ed. I $(M=31.239, S D=3.8308)$ and D.El.Ed. III $(M=31.630, S D=3.8202)$ semester is not significant $(\mathrm{t}=0.491)$ at 0.05 level. All results indicate that D.El.Ed. III semester pupil teachers adopt 
more 'Avoiding', and 'Compromising' conflict style than pupil teachers of D.El.Ed. I semester but students of both the semesters give equal priority to 'Collaborating', 'Integrating', 'Dominating', 'Obliging', and 'Reasoning' styles of conflict management.

Table 3

Mean, SD, and t-ratios showing difference between students of urban and rural localities on seven conflict management styles

\begin{tabular}{|c|c|c|c|c|c|c|c|}
\hline Conflict management style & Locality & $\mathbf{N}$ & Mean & Std. Deviation & df & t-ratio & p-value \\
\hline \multirow{2}{*}{ Avoiding } & Urban & 30 & 22.767 & 4.4310 & \multirow{2}{*}{90} & \multirow{2}{*}{.387} & \multirow{2}{*}{.700} \\
\hline & Rural & 62 & 23.129 & 4.1031 & & & \\
\hline \multirow{2}{*}{ Compromising } & Urban & 30 & 22.633 & 5.6476 & \multirow{2}{*}{90} & \multirow{2}{*}{.938} & \multirow{2}{*}{.351} \\
\hline & Rural & 62 & 23.758 & 5.2626 & & & \\
\hline \multirow{2}{*}{ Collaborating } & Urban & 30 & 32.500 & 3.9545 & \multirow{2}{*}{90} & \multirow{2}{*}{1.194} & \multirow{2}{*}{.236} \\
\hline & Rural & 62 & 31.532 & 3.4864 & & & \\
\hline \multirow{2}{*}{ Integrating } & Urban & 30 & 30.667 & 3.7077 & \multirow{2}{*}{90} & \multirow{2}{*}{.139} & \multirow{2}{*}{.890} \\
\hline & Rural & 62 & 30.548 & 3.8822 & & & \\
\hline \multirow{2}{*}{ Dominating } & Urban & 30 & 25.567 & 4.8756 & \multirow{2}{*}{90} & \multirow{2}{*}{.706} & \multirow{2}{*}{.482} \\
\hline & Rural & 62 & 24.806 & 4.8276 & & & \\
\hline \multirow{2}{*}{ Obliging } & Urban & 30 & 19.867 & 4.4624 & \multirow{2}{*}{90} & \multirow{2}{*}{1.284} & \multirow{2}{*}{.202} \\
\hline & Rural & 62 & 21.258 & 5.0536 & & & \\
\hline \multirow{2}{*}{ Reasoning } & Urban & 30 & 31.067 & 3.6571 & \multirow{2}{*}{90} & \multirow{2}{*}{.643} & \multirow{2}{*}{.522} \\
\hline & Rural & 62 & 31.613 & 3.8977 & & & \\
\hline
\end{tabular}

It was hypothesized that "There is no significant difference in conflict management style of pupil teachers belonging urban and rural area." This hypothesis was tested with reference to seven conflict management styles namely 'Avoiding', 'Compromising', 'Collaborating', 'Integration', 'Dominating', 'Obliging', and 'Reasoning' styles. Table 3 shows a comparison of students of D.El.Ed. students of urban and rural area on seven dimensions of conflict management style. The higher score on the conflict management style is indicative of higher exercise of that style of conflict management by the students. On avoiding style, the difference between students of urban $(M=22.767, S D=4.4310)$ and rural $(M=23.129, S D=4.1031)$ is not significant $(\mathrm{t}=0.387)$ at 0.05 level. On compromising style, the difference between students of urban $(M=22.633, S D=5.6476)$ and rural $(M=23.758$, $S D=5.2626)$ is not significant $(\mathrm{t}=0.938)$ at 0.05 level. On collaborating style, the difference between students of urban $(M=32.500, S D=3.9545)$ and rural $(M=31.532, S D=3.4864)$ is not significant $(\mathrm{t}=1.194)$ at 0.05 level. On integrating style, the difference between students of urban $(M=30.667, S D=3.7077)$ and $\operatorname{rural}(M=$ $30.548, S D=3.8822)$ is not significant $(\mathrm{t}=0.139)$ at 0.05 level. On dominating style, the difference between students of urban $(M=25.567, S D=4.8756)$ and rural $(M=24.806, S D=4.8276)$ is not significant $(\mathrm{t}=0.706)$ at 0.05 level. On obliging style, the difference between students of urban $(M=19.867, S D=4.4624)$ and $\operatorname{rural}(M=$ $21.258, S D=5.0536)$ is not significant $(\mathrm{t}=1.284)$ at 0.05 level. On reasoning style, the difference between students of urban $(M=31.067, S D=3.6571)$ and rural $(M=31.613, S D=3.8977)$ is not significant $(\mathrm{t}=0.491)$ at 0.05 level of significance. To sum up it can be inferred that pupil teachers of urban and rural areas give equal preference to various conflict management style.

Table 4

Summary of the results of ANOVA showing differences on

Conflict Management among D.El.Ed. students of different social categories

\begin{tabular}{|c|c|c|c|c|c|c|}
\hline \multicolumn{2}{|c|}{ Conflict management style } & Sum of Squares & df & Mean Square & $\mathbf{F}$ & p-value \\
\hline \multirow{2}{*}{ Avoiding } & Between Groups & 66.189 & 2 & 33.094 & \multirow{2}{*}{1.922} & \multirow{2}{*}{0.152} \\
\hline & Within Groups & 1532.8 & 89 & 17.222 & & \\
\hline \multirow{2}{*}{ Compromising } & Between Groups & 24.699 & 2 & 12.349 & \multirow{2}{*}{0.42} & \multirow{2}{*}{0.658} \\
\hline & Within Groups & 2615.214 & 89 & 29.384 & & \\
\hline \multirow{2}{*}{ Collaborating } & Between Groups & 27.766 & 2 & 13.883 & \multirow{2}{*}{1.042} & \multirow{2}{*}{0.357} \\
\hline & Within Groups & 1186.104 & 89 & 13.327 & & \\
\hline \multirow{2}{*}{ Integrating } & Between Groups & 20.376 & 2 & 10.188 & \multirow{2}{*}{0.699} & \multirow{2}{*}{0.5} \\
\hline & Within Groups & 1297.929 & 89 & 14.583 & & \\
\hline \multirow{2}{*}{ Dominating } & Between Groups & 26.668 & 2 & 13.334 & \multirow{2}{*}{0.566} & \multirow{2}{*}{0.57} \\
\hline & Within Groups & 2096.06 & 89 & 23.551 & & \\
\hline \multirow{2}{*}{ Obliging } & Between Groups & 11.732 & 2 & 5.866 & \multirow{2}{*}{0.241} & \multirow{2}{*}{0.786} \\
\hline & Within Groups & 2162.747 & 89 & 24.301 & & \\
\hline \multirow{2}{*}{ Reasoning } & Between Groups & 42.88 & 2 & 21.44 & \multirow{2}{*}{1.493} & \multirow{2}{*}{0.23} \\
\hline & Within Groups & 1277.729 & 89 & 14.357 & & \\
\hline
\end{tabular}


It was hypothesized that 'there is no significant difference in conflict management style of pupil teachers belonging to different social categories.' ANOVA was used to test this hypothesis was tested with reference to all seven dimensions of conflict management style. Table 4 shows that the value of $\mathrm{F}$ ratio for avoiding conflict management style is $1.952(\mathrm{df}=2,89)$. It is not significant at 0.05 level. It means that there is no significant difference among pupil teachers of various social categories on avoiding style of conflict management. The value of $\mathrm{F}$ ratio for compromising conflict management style is $0.420(\mathrm{df}=2,89)$. It is not significant at 0.05 level. It means that there is no significant difference among pupil teachers of various social categories on compromising style of conflict management. The value of $\mathrm{F}$ ratio for collaborating conflict management style is $1.042(\mathrm{df}=2,89)$. It is not significant at 0.05 level. It means that there is no significant difference among pupil teachers of various social categories on compromising style of conflict management. The value of $F$ ratio for integrating conflict management style is $0.699(\mathrm{df}=2,89)$. It is not significant at 0.05 level. It means that there is no significant difference among pupil teachers of various social categories on integrating style of conflict management. The value of $\mathrm{F}$ ratio for dominating conflict management style is $0.566(\mathrm{df}=2,89)$. It is not significant at 0.05 level. It means that there is no significant difference among pupil teachers of various social categories on dominating style of conflict management. The value of $\mathrm{F}$ ratio for obliging conflict management style is $0.241(\mathrm{df}=2,89)$. It is not significant at 0.05 level. It means that there is no significant difference of social category on obliging style of conflict management. The value of $\mathrm{F}$ ratio for reasoning conflict management style is $1.493(\mathrm{df}=2,89)$. It is not significant at 0.05 level. It means that there is no significant difference of social category on reasoning style of conflict management. Results indicate that pupil teachers of D.El.Ed. course belonging to different social categories give equal preference to adoption of 'Avoiding', 'Compromising', 'Collaborating', 'Integrating', 'Dominating', 'Obliging', and 'Reasoning' conflict management styles.

\section{Conclusion}

1. Male and female pupil teachers of D.El.Ed. course give equal preference to adoption of 'Avoiding', 'Compromising', 'Collaborating', 'Integrating', and 'Reasoning' conflict management style. The similarity in adoption of avoiding style in male and female students appears to reflect social ethos as in paves the way to peace of mind. However, male pupil teachers give more preference to adoption of 'Dominating', and 'Obliging' conflict management in comparison to female pupil teachers.

2. D.El.Ed. III semester pupil teachers adopt more 'Avoiding', and 'Compromising' conflict style than pupil teachers of D.El.Ed. I semester but students of both the semesters give equal priority to 'Collaborating', 'Integrating', 'Dominating', 'Obliging', and 'Reasoning' styles of conflict management.

3. D.El.Ed. pupil teachers of urban and rural areas give equal preference to various conflict management style 'Avoiding', 'Compromising', 'Collaborating', 'Integrating', 'Dominating', 'Obliging', and 'Reasoning'.

4. D.El.Ed. pupil teachers belonging to different social categories give equal preference to adoption of 'Avoiding', 'Compromising', 'Collaborating', 'Integrating', 'Dominating', 'Obliging', and 'Reasoning' conflict management styles.

\section{References}

- Coser, L.A. (1967). Continuities in the Study of Social Conflict. New York: Free Press.

- Deutsch, M. (1973). The Resolution of Conflict. New Haven: Yale University Press

- Encyclopedia Britannica, 5, 1973, p. 874

- Ghaffar, A. (2009). Conflict in Schools: Its Causes \& Management Strategies. Journal of Managerial Sciences, 3(2)

- Johnson, D. W., and R. Johnson. (1979). "Conflict in the Classroom: Controversy and Learning." Review of Educational Research 49, 1: 51-61.

- M., Idris, R., Ali, \& A., Ghaffar. (2017). Investigation into the Nature and Causes of Students' Conflicts, Strategies and Role of Academic Personnel in Conflicts Resolution in Universities of Khyber Pakhtun Khwa. In Pakistan Journal of Education 1(34), 127-142.

- Meusel, Alfred. (1934). "Revolution and counter revolution." Encyclopaedia of the Social Sciences, Vol. 13, New York: Macmillan, 367-376.

- Willmot, W.W., and J.L. Hocker (2001). Interpersonal Conflict. New York: McGraw-Hill. 